\title{
Superstitions, religiosity and secularization: an analysis of the periodic oscillations of weddings in Italy
}

\author{
Marco Breschi ${ }^{\dagger}$ and Gabriele Ruiu ${ }^{* \dagger}$
}

\author{
* Correspondence: gruiu@uniss.it \\ †Equal contributors \\ Dipartimento di Scienze \\ Economiche e Aziendali, Università \\ degli Studi di Sassari, Via Muroni, 25, \\ Sassari, Italy
}

\begin{abstract}
Using exhaustive data on all of the marriages celebrated in Italy 2007-2009, we investigated the influence of superstition and religious beliefs on the choice of wedding dates. We compared our results with those relative to postwar Italy, gathered together by Nora Federici. Surprisingly, we found that superstition has a constant effect in all areas of the country. At the same time, there were different levels of religious secularization. We also found that education was not a negative factor for religiosity.
\end{abstract}

Keywords: Superstition, Religion, Marriage seasonality, Secularization

\section{Introduction}

Livi-Bacci (2000) noted how, as scientific discipline advances, a curious paradox emerges: the need for new knowledge increases, but this need does not obey what economists call "the law of diminishing returns". However, the rise in the number of research topics in an increasingly complex modern society inevitably leads to the abandonment of some "old-fashioned" subjects. This, at least, has been the case with the periodic oscillations of marriages, which appeal less and less to demographers. To get a rough quantification of this decline in interest, we ran a research enquiry through the JSTOR repository, using the keywords: "seasonal" and "marriage" (as a criterion of research, we only require that these two words appear together in the text, so we are certainly overestimating the number of articles on the topic). We found that, over the last decade, the number of papers with these words has roughly halved. ${ }^{1}$ The falling off of interest is also evident in the disappearance of seasonal decomposition from the principle textbooks employed for demographic methodology. For instance, one of most read textbooks in Italy, ${ }^{2}$ in the 1960s and 1970s, was written by Federici $(1955,1960$, $1965,1981)$. In these volumes an Italian demographer dedicated an ad hoc chapter to seasonality. ${ }^{3}$ The special attention paid to the analysis of seasonality reflects the research interests of Federici. But her chapter is also a reminder of the quality of the Italian historical demographers of that time who were at the cutting edge, in terms of their originality and methodological accuracy, in the study of short-term fluctuations in demographic events. Italian scientific production in those years was copious, so copious, indeed, that we cannot give a comprehensive list of references here. However, it is enough

(C) 2016 The Author(s). Open Access This article is distributed under the terms of the Creative Commons Attribution 4.0 International License (http://creativecommons.org/licenses/by/4.0/), which permits unrestricted use, distribution, and reproduction in any medium, provided you give appropriate credit to the original author(s) and the source, provide a link to the Creative Commons license, and indicate if changes were made. 
to look at works published from the mid-1930s onwards, in the bibliographic section of the 10th volume produced by the Comitato Italiano per gli Studi della Popolazione (CISP 1941). Thereafter, they appear in the excellent repertories, edited by Golini (1966) from 1930 to 1965 and by Golini and Caselli (1973) for 1966 to 1971. See also Sonnino (1997) for the works produced in the ambit of historical demography, from 1940 to 1993 . There were various issues analysed, often with great verve. Among the most intriguing works, Federici (1964) must be citied, where she exploited an ad hoc exposure of the 1958 registrations of Italian marriages. Federici took up "an interesting aspect but one that is almost ignored in the periodic oscillations of marriages [...] that inherent in the different frequencies that characterize the days, the months and some particular periods of the year" (our translation of Federici 1964, p.25). Commenting on her own work on the topic, Federici observed that "the analysis carried out for Italy shows that, even in the late 1950s, the influence of superstitions in the choice of the wedding dates was clear: very few people got married on the 17th day of the month and Tuesdays and Fridays, and this phenomenon was generalized across all Italy. A narrow examination of the date fluctuations also reveals an extraordinary concentration of marriages on days of religious or civil importance: this last aspect shows, however, more territorial heterogeneity [...] an examination of the current situation is not possible due to the lack of data, however, there are reasons for presuming that the phenomenon is still operating" (our translation, Federici 1981, p. 445). ${ }^{4}$ Furthermore, in the concluding remarks of her 1964 paper, Federici argued that the real research question for the superstitious or religious influence of day-of-marriage oscillations did not concern where these beliefs about marriages came from, but rather, whether or not these beliefs would survive economic and social progress.

In regard to the effect of religious beliefs, Federici found that during Easter week the celebration of marriages was largely avoided: this was, in all Italy, the week with the fewest ceremonies. This phenomenon was due to an ancient Catholic rule that forbade the solemnization of marriages (i.e. the priest's benediction and the nuptial mass) during the periods of spiritual preparation preceding the two main Christian festivals. These were, of course, Advent (i.e. the 4 weeks before Christmas, a period of four Sundays, starting in the last week of November or in the very first days of December) and Lent (the period of 40 days from Ash Wednesday to Holy Thursday, Easter is a moveable feast, so the starting date of Lent floats between 4 February and 10 March). During Easter week, this ban becomes total since from Good Friday to Easter Sunday, marriages were strictly prohibited. In general, the ban associated with the Lenten period was more strongly enforced than the Advent ban (Lesthaeghe and Lopez-Gay 2013, Van Poppel 1995). This was probably due to the different nature of the feasts. In addition, the introduction, in the twentieth century, of paid Christmas holidays may have facilitated the participation of friends and relatives in the ceremonies, thus favouring December for weddings (see Dribe and van De Putte 2012).

Despite some data access problems, the limitations encountered by Federici can be overcome, at least for more recent periods. ${ }^{5}$ Therefore, our work, which is based on an exhaustive data collection of all marriages celebrated in Italy, 2007-2009, can take up Federici's question. Are superstitious and religious norms still important in choosing wedding dates after the great changes that Italy has been through: the country, after all, has shifted from an agriculturally based to an advanced economy; from a "young" to an "old" country; and from a homogenous to a multicultural society? After having answered this question, we will dig deeper into the religious aspects of marriage by 
investigating what spousal socio-demographic characteristics are correlated (and obviously the directions of these correlations). We do this both in terms of the choice of whether to marry with a religious rite and the tradition of not getting married during the Lenten period. This second analysis is exploratory in nature. However, we believe that it could prove interesting. For instance, once we have taken into account the effect of other possible confounding factors, are better educated people more or less inclined to marry in church? Also, are better educated couples more or less inclined to respect religious rules?

We believe that this topic offers a contribution to the debate opened up in various branches of the social sciences about the influence of cultural factors in determining individual behaviour. Cultural values and beliefs are, in fact, increasingly accepted as determinants of individual choices and behaviour. For instance, in the demographic literature, Lesthaeghe and Surkyn (1988) and Lesthaeghe and Lopez-Gay (2013) consider religious secularization as one of prerequisites for the second demographic transition. Fernandez and Fogli (2009) show, empirically, the significant influence of cultural beliefs prevailing in a father's country of origin on the fertility decisions of secondgeneration immigrants in the USA. In economics, there are various empirical works that, building on the Weberian theory of the origin of modern capitalism, relate religious beliefs to different kinds of economic outputs (among others Barro and McCleary 2003, McCleary and Barro 2006, Guiso et al. 2003, Tabellini 2010).

The present work is organized as follows: in the next section, we will briefly present a review of the literature on the effects of superstitious and religious beliefs on the timing of weddings; in the third section, after having briefly presented our data, we will try to understand the persistence in time of religious and superstitious beliefs. We will do so by comparing the descriptive statistics offered by Federici in the late 1950s with those worked up 50 years afterwards. We will also present the results of our exploratory analysis on the choice of marrying with the religious rite and on the tendency to respect the Lenten ban imposed by the Catholic Church on marriages. We round off the work with some general considerations.

\section{Religion, superstition and the wedding calendar: a brief literature review}

The influence of religious proscriptions on the wedding calendar has often been remarked on in demography, sociology and anthropology. In particular, it has been frequently observed that in Catholic countries the ban on the solemnization of marriages imposed by the Catholic Church during Lent and Advent operated a significant deterrent effect on their celebration in March (this month is almost entirely included in Lent independently of when Easter is celebrated) and December (the Advent period generally begins on the last Sunday of November).

It must be noted that the effects of Advent are more nuanced, as the Advent ban is characterized by a different degree of enforcement, even in different regions of the same country (see Ruiu and Breschi 2015 for a discussion).

Lent and Advent are used by Lesthaeghe and Lopez-Gay (2013) to measure the level of religious secularization in Belgium and Spain. González-Martín (2008), meanwhile, analysed the seasonality of marriage in the Principality of Andorra over a very long time span: 1600-1960. He found that, right through this period, March had the lowest 
number of celebrations and he concluded that this was caused by the Lenten effect. With regard to Advent, he found that celebrants began to ignore this ban in the early twentieth century. Likewise, Arsenovic et al. (2015) concluded that, in Sajkaska (Republic of Serbia), religion had a huge impact on seasonality up to the twentieth century.

Van Poppel (1995) focused on the Netherlands from 1812 to 1912, reporting no signs of secularization (measured by respect for the seasonal wedding ban) in the Catholic regions of the country.

In his empirical work, focused on 1927-1938, Bourgeois-Pichat (1946) reported a great degree of heterogeneity in religious secularization among the different French regions. In particular, he found that the northwest of that country had less respect for religious norms regarding "forbidden" periods, while, in the southwest, people were more inclined to respect them. In regard to France, Houdaille (1978) analysed respect for religious norms on weddings from 1740 to 1829, highlighting a substantial increase in celebrations in both Advent and Lent during the tumultuous years of the French revolution (1793-1799).

Focusing on Italy from 1880 to 1969 , Chiassino and Di Comite (1972) show that all Italian regions respected marriage seasonality. Similarly, Ruiu and Breschi (2015) implemented a long-run analysis (1862-2012) of marriage seasonality across the Italian regions. They showed that, while Lent has a less marked effect than a century ago, it is still able to dampen down the number of Lenten weddings.

There are also empirical works that testify to the influence of religion on marriage seasonality at the regional level: Coppa et al. (2001) analysed the case of Abruzzo, while Sanna and Danubio (2008) studied marriage seasonality in Sardinia.

In regard to superstitions, there is a rich literature showing that May is considered a particularly unlucky month for celebrating marriages in France, in French-speaking Switzerland and in some regions of Italy. Monger (1994) has observed that the superstition about May was also common in England: his analysis is focused on Essex. Bonneuil and Fursa (2013) report the widely held belief among Russian Orthodox populations that May marriages mark couples down for indigence.

For some authors, the beliefs about May derived from the consecration of the month to the Virgin Mary (Bourgeois-Pichat 1946). Others attribute this credence to a cultural legacy from Roman times. Indeed, Plutarch, in his Roman Questions, reported that in May one of the main rituals of purification, "the feast of the Argei", was carried out. As a result, marriage celebrations would have been, according to Roman beliefs, ominous (see Perrenoud 1983 for a discussion of other possible explanations).

Lutinier (1987), continuing the work of Bourgeois-Pichat, analysed both Lenten and May beliefs, from 1955 to 1983 . He found that even if the deterrent effect of the Lenten period had been diluted over time, rural regions were still more inclined to avoid the 40 days. In regard to superstitions, somewhat paradoxically, Lutinier found that superstitions about May were still able to significantly affect marriage seasonality.

Salvat et al. (1997) focused on 20 Spanish communities in the period 1918-1983 and 27 French communities in the period 1836-1990, all situated in the Cerdanya Valley (a region in the eastern Pyrenees on the border between France and Spain). All these communities have the same cultural roots and similar economic-activity profiles, so at least in principle, they should have the same seasonal pattern of marriages. However, with the Treaty of the Pyrenees in 1659 , these communities were arbitrarily assigned to 
French or Spanish rule and thus found themselves subject to different cultural influences. Salvat et al. reported that, through this period, the "Frenchification" of the upper part of the Cerdanya Valley became evident. May superstitions were taken seriously in that territory, while they were simply unknown in the Spanish part of the valley.

Also, Lucchetti et al. (1996) compare marriage seasonality among nine communities at the crossroads between France, Spain and Italy, from 1800 to 1980: they took three communities in each country. They found that religious norms regarding Lent were respected in all nine communities, but that May credence was found only in the French communities and in one out of three Italian communities.

Bonneuil and Fursa (2013) analysed a very interesting area, in terms of religious diversity, "The Don region" in Southern Russia from 1867 to the eve of the Russian Revolution. The analysis of this region allowed them to evaluate how the different religious calendars and popular beliefs associated with the different faiths of the area affected marriage seasonality. They found that for all the faiths in question (Roman Catholics, Armenian-Gregorians, Lutherans Orthodox and Old Believers), respect for the religious calendar was strong and undiminished over time in rural regions. However, in urban areas Armenian-Gregorians, Catholics and Lutherans emancipated themselves from their religious calendars. May superstitions were only relevant for Orthodox believers.

As to non-European countries, Barrett (1990) reports that the New Year period is considered particularly auspicious for marriages among the Chinese, while the seventh lunar month is a period to be avoided. Kaku and Matsumoto (1975) reported that, in Japan, marriages are often celebrated on the days designated as tai-an, days of "great peace", when it is believed that success attends acts.

Finally, focusing on Italy, in addition to Federici's work, previous research by Corridore (1906) must also be cited. In particular, Corridore stressed how Tuesdays and Fridays were unpopular days for weddings. The same author explains this finding by citing the Italian proverb "né di venere né di marte ci si sposa né si parte (our translation "Neither on Friday nor on Tuesday, should you marry or start a journey"). The influence of these superstitious beliefs on determining the timing of weddings is also documented in studies carried out at the regional level (Forgione 2015 on Lucania, Angius 2006 on Sardinia). See also Ferigo (1998a, b) who focused on May superstitions in Friuli Venezia Giulia.

\section{An empirical analysis of the effect of superstitious and religious beliefs on wedding dates \\ Data source}

Before commenting on the differences between Federici's findings and our results, we offer a brief introduction to the data sources used. All the analyses presented in this section of the paper are based on the "Rilevazione annuale dei matrimoni da fonti di stato civile" for the period 2007-2009. This data source accounts for all the marriages legally recognized by the Italian Republic. In particular, every minister (both civil and religious) who has celebrated a civilly valid marriage in Italy, must fill out a form with detailed information about both the marriage (date, place, patrimonial regime chosen by the spouses and type of rite) and the spouses (date of birth, place of birth and of residence, nationality, occupation and level of education). These forms are then 
collected by the Italian Official Statistics Institute (ISTAT). In the case of marriages celebrated with the religious rite, we are speaking of the so-called matrimonio concordatario, i.e. a religious marriage recognized by the state, thanks to an official agreement between the representatives of a religious group and the Italian State. These religious groups are the Roman Catholic Church; the Italian Union of Adventist Churches; the Italian Union of Jewish Communities; the Italian Union of the Evangelical Lutheran Churches; the Italian Union of the Baptist Churches; the Waldesian Church; and the Italian Pentecostal Evangelical Church. Even if not all religious marriages are celebrated with this formula, at least for Catholic marriages, in the vast majority of cases (more than $80 \%$ of all Catholic marriages), the marriage is a "matrimonio concordatario" (see Bonarini 2013 for more detailed data and for a discussion). The procedure to get access to these data is particularly long and complex because of the severe privacy norms protecting them. The following steps need to be undertaken to access material: (1) the interested researcher has to present a research project asking for access to the data; (2) the project is evaluated by the General Direction of ISTAT; (3) if authorization is granted, the researcher does not enter into possession of the data but he or she has to elaborate them in the relevant data laboratory in a regional ISTAT office; (4) all the outputs produced have to be submitted again to the General Direction, for a last check to guarantee the non-infringement of privacy rules. These steps are the principle reason that we have focused on such a short time period, exactly 50 years after Federici's analysis. To the best of our knowledge, this is the first empirical work in this area using ISTAT data (save, of course, that conducted by Federici herself).

\section{The time persistent effect of religion and superstition on the marriage calendar}

Tuesday and Friday are, in Italian superstition, two days that should be avoided for celebrating marriages. In his essay on Italian superstitions, Di Nola (1993) argued that the superstition about Tuesday may stem from the fact that in Roman times, this was the day of the God of War, which in popular lore has become the day of discord and enmity, and so is one ill-suited to marriage. In regard to Friday, the belief probably originates from the fact that according to Christian tradition, this is the day that Jesus Christ died and was, therefore, a day of penance. It must be said that the Catholic Church does not impose a ban on the celebration of marriages on this day, but only a "lean" day without meat: an act of penance that can be replaced with charitable actions. The idea of negative consequences for marrying on Friday, then, may have a religious origin, but it is not based on any religious rule.

As first evidence of the deterrent effect of superstitions, Federici (1964) reported that, in September and October 1958, the average number of marriages on Tuesday and Friday stood at, respectively, 145 and 36 compared with a daily mean of 1773 . In regard to territorial variations, Federici showed that the reluctance to marry on these two days was evident in all Italian regions. However, she also noted that spouses in Northern and Central Italy seemed to be more careful than those in Southern Italy in avoiding these unlucky days. What has changed 50 years later?

For the period 2007-2009, Table 1 reports the average number of marriages by week day celebrated with civil (panel A) and religious (panel B) rites in Italy and in the five macro-areas originally considered by Federici. ${ }^{6}$ The italicized characters highlight the 
Table 1 Average number of marriages per day of the week, Italy and its macro-areas, 2007-2009

\begin{tabular}{|c|c|c|c|c|c|c|c|c|c|c|c|c|}
\hline & \multicolumn{2}{|l|}{ Ita. } & \multicolumn{2}{|l|}{ N.W. } & \multicolumn{2}{|l|}{ N.E. } & \multicolumn{2}{|l|}{ C. } & \multicolumn{2}{|l|}{ S. } & \multicolumn{2}{|l|}{$|s|}$. \\
\hline & $\overline{N_{j}}$ & $I_{j}$ & $\overline{N_{j}}$ & $I_{j}$ & $\overline{N_{j}}$ & $I_{j}$ & $N_{j}$ & $I_{j}$ & $\overline{N_{j}}$ & $I_{j}$ & $\overline{N_{j}}$ & $I_{j}$ \\
\hline \multicolumn{13}{|c|}{ A. Civil marriages } \\
\hline Sunday & 118.6 & 49.4 & 27.6 & 37.7 & 6.5 & 19.7 & 66.8 & 89.4 & 13.3 & 36.0 & 4.4 & 20.0 \\
\hline Monday & 145.9 & 60.8 & 44.4 & 60.7 & 13.9 & 41.8 & 35.3 & 47.2 & 36.7 & 99.3 & 15.6 & 71.0 \\
\hline Tuesday & 87.9 & 36.6 & 22.9 & 31.4 & 11.0 & 33.1 & 16.4 & 22.0 & 20.5 & 55.6 & 17.0 & 77.3 \\
\hline Wednesday & 126.3 & 52.6 & 24.0 & 32.8 & 13.0 & 39.3 & 39.0 & 52.1 & 30.5 & 82.5 & 19.9 & 90.5 \\
\hline Thursday & 242.5 & 101.1 & 62.4 & 85.4 & 21.3 & 64.3 & 61.6 & 82.4 & 68.8 & 186.4 & 28.4 & 129.0 \\
\hline Friday & 141.7 & 59.1 & 42.6 & 58.3 & 18.2 & 55.0 & 37.5 & 50.1 & 25.6 & 69.2 & 17.8 & 81.0 \\
\hline Saturday & 819.1 & 341.4 & 288.8 & 395.0 & 148.7 & 448.2 & 267.7 & 358.1 & 63.1 & 170.8 & 50.9 & 231.4 \\
\hline Total & 240.0 & 100.0 & 73.1 & 100.0 & 33.2 & 100.0 & 74.8 & 100.0 & 36.9 & 100.0 & 22.0 & 100.0 \\
\hline \multicolumn{13}{|c|}{ B. Religious marriages } \\
\hline Sunday & 398.3 & 94.0 & 82.4 & 101.5 & 32.0 & 84.3 & 156.4 & 170.5 & 101.5 & 67.6 & 26.0 & 41.4 \\
\hline Monday & 183.3 & 43.3 & 22.7 & 27.9 & 3.3 & 8.7 & 18.8 & 20.5 & 110.0 & 73.2 & 28.6 & 45.6 \\
\hline Tuesday & 90.9 & 21.4 & 7.1 & 8.7 & 1.9 & 5.0 & 6.6 & 7.2 & 44.6 & 29.7 & 30.7 & 48.9 \\
\hline Wednesday & 162.8 & 38.4 & 11.3 & 14.0 & 1.7 & 4.4 & 10.8 & 11.8 & 92.2 & 61.4 & 46.8 & 74.6 \\
\hline Thursday & 240.6 & 56.8 & 22.3 & 27.5 & 2.2 & 5.8 & 19.9 & 21.7 & 144.2 & 96.0 & 52.0 & 82.8 \\
\hline Friday & 200.2 & 47.2 & 38.2 & 47.1 & 3.9 & 10.4 & 22.5 & 24.5 & 86.9 & 57.8 & 48.6 & 77.5 \\
\hline Saturday & 1697.8 & 400.5 & 386.3 & 475.5 & 221.3 & 583.8 & 409.1 & 446.0 & 473.8 & 315.3 & 207.3 & 330.2 \\
\hline Total & 423.9 & 100.0 & 81.2 & 100.0 & 37.9 & 100.0 & 91.7 & 100.0 & 150.3 & 100.0 & 62.8 & 100.0 \\
\hline
\end{tabular}

Source: our elaborations on "Rilevazione annuale dei matrimoni da fonti di stato civile, 2007-2009"

day of minimum concentration. To better allow territorial comparability, we also report an index, calculated in the following way:

$$
l_{j}=\frac{N_{j}}{N_{07-09}} * 100 \text { for } j=\text { Sunday, Monday, } \ldots
$$

where $N_{j}$ is the average number of marriages celebrated in day $j$, while $N_{07-09}$ is the daily average number of celebrations for 2007-2009.

In regard to civil marriages, the North East, the South and the Islands are the macroareas where Sunday is the day of minimum concentration, just below what was recorded on Tuesday. However, it must be noted that these results partly depend on the availability of local civil officials. In general, the spouses are constrained by town council regulations. In some cities, marriages can be celebrated on Sundays (the day when public offices are closed), while, in others, spouses can only choose from the other days of the week. ${ }^{7}$ Therefore, the results that are associated with Sunday must be read in the light of these dispositions.

For religious marriages, at first, we were surprised by the results from the Islands. In fact, with the exception of this macro-area, Tuesday is, everywhere, the day that has fewest weddings. However, the Islands is driven by Sicily (55,673 Sicilian celebrations against 13,128 Sardinian celebrations), where the regional conference of bishops has established that celebrations are not allowed on Sundays (the day dedicated to God). ${ }^{8}$ Therefore, in Sicily, those who opt for the religious rite can only choose from six days of the week, not seven. This, naturally, leads to an increase in the number of Tuesday weddings. 
Federici noted, 50 years ago, that Central Italy was the area where people care the most about not getting married on unlucky days (together with the North East, if we consider religious marriages). This still seems to be the case 50 years later.

If the Tuesday superstition is still operating, there is, for Friday, a diminution in belief with respect to the situation depicted by Federici. Here let us offer two considerations. First of all, a recent survey carried out by an Italian Association of consumers (Federconsumatori) reported that the cost for marriage is substantially lower when it is celebrated from Monday to Friday, rather than on Saturday or Sunday. The amount that is saved by marrying on one of the weekdays could amount to $25 \%$ of the total cost, if the marriage is celebrated in summer (the season when most weddings take place in Italy). Second, Friday is very near to the weekend and, therefore, offers the possibility of the greater participation of friends and relatives, especially in the evening, due to the potential day off work. So, economic convenience, together with the proximity of the weekend, makes this day, at least in principle, a good choice. Furthermore, if spouses plan to organize their honeymoon after the ceremony, thanks to the proximity to the weekend, they may save days of work leave since Saturday and Sunday are generally days in which people are free from work. Indeed, someone ignorant of the relevant superstitions might have expected Friday to have a greater appeal.

We now focus on another another superstition, "the heptadecaphobia" (the fear of the number 17), which is less subject to the bias produced by local religious/civil dispositions. In all of the Italian regions, the number 17 is considered unlucky. According to Federici's analysis, this belief was clearly reflected in the dramatic contraction of the number of weddings celebrated on the 17th of each month. In particular, Federici reported that the deterrent effect was widespread in all of regions, with the strongest effect produced in Central Italy.

In Fig. 1 (panels a and b), we report, for each macro-area, an index built in a similar way with respect to equation (1), but using as the numerator the average number of marriages celebrated on each day from the first to the 31st and the daily average number of marriages for the entire 2007-2009 period as the denominator. Heptadecaphobia seems to be diffused to the same extent in all macro-areas. Federici declared that she was surprised that Southern Italy, which is usually seen as more traditionalist than the North, did not stand out and perhaps was even less superstitious in this respect. We have the same findings 50 years later.

It is also worth noting that the deterrent effect played by the number 17 operates for both civil and religious marriages, though note that "17" marriages are slightly less likely in religious marriages.

We also looked at the combination of Friday with the 17th day of the month.

This day is the Italian equivalent of the Anglo-Saxon Friday the 13th: it is, in other terms, the day that, according to superstition, must be absolutely avoided. It should be noted that Friday the 17th weddings were so rare that we were not able to make the same macro-decompositions in Italian territories proposed in Table 1, without violating one of ISTAT's privacy norms. ${ }^{9}$ In particular, we had to pool together the North West and the North East of the country. ${ }^{10}$ We were, likewise, not able to produce a table that distinguished the types of rite (religious or civil) chosen by spouses. Table 2, nevertheless, reports the number of marriages celebrated on each Friday the 17th in the 3-year period 2007-2009 in comparison to the number of marriages celebrated on the other 


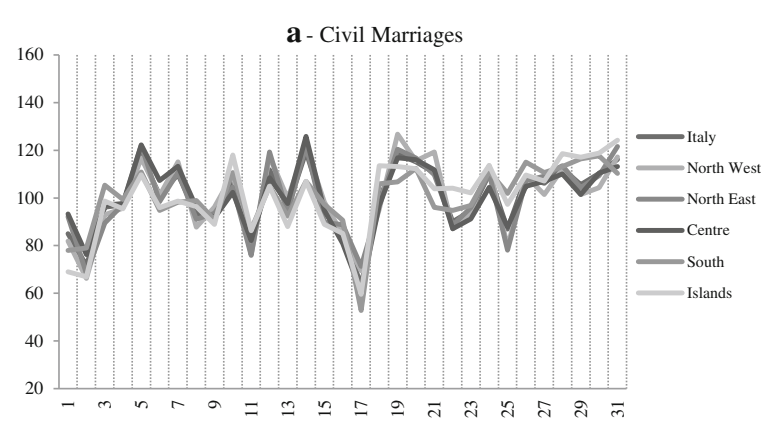

b- Religious Marriages

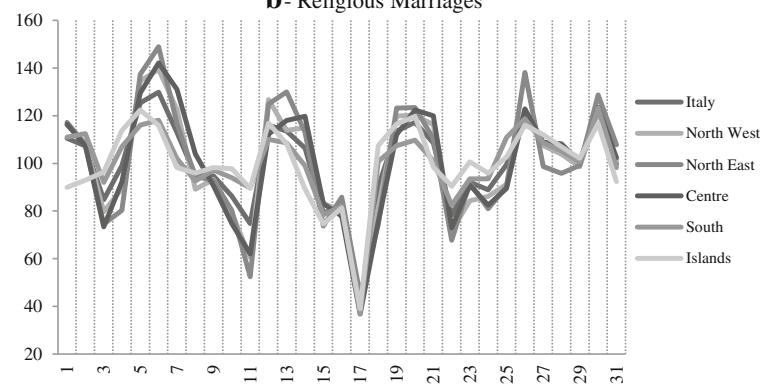

Fig. 1 a, b The effect of the superstition of the 17th day on marriages. Italy and macro-areas, 2007-2009

Fridays of the same month and with the average daily number of marriages celebrated in the corresponding month. In general, the frequencies calculated for each Friday are lower than the daily average of the respective month. However, in the case of Friday the 17th, a further depressive effect is evident.

It is worth noting that, in the case of marriages celebrated in April 2009, 10 April is Good Friday. This is a unique case in which a Friday that is not the 17th of the month has the lowest frequency.

Table 2 Marriages (civil and religious) celebrated on Friday the 17th in Italy, 2007-2009

\begin{tabular}{|c|c|c|c|c|c|c|c|c|c|c|c|}
\hline MM/DD/YYYY & Ita. & $\mathrm{N}$ & C. & S. & |s|. & MM/DD/YYYY & Ita. & $\mathrm{N}$ & C. & S. & $|s|$. \\
\hline $8 / 3 / 2007$ & 470 & 109 & 59 & 206 & 96 & 4/3/2009 & 143 & 67 & 24 & 33 & 19 \\
\hline $8 / 10 / 2007$ & 431 & 52 & 39 & 213 & 127 & $4 / 10 / 2009$ & 120 & 65 & 21 & 18 & 16 \\
\hline 8/17/2007 & 146 & 21 & 23 & 66 & 36 & $4 / 17 / 2009$ & 125 & 50 & 29 & 32 & 14 \\
\hline $8 / 24 / 2007$ & 382 & 73 & 51 & 155 & 103 & 4/24/2009 & 487 & 183 & 60 & 151 & 93 \\
\hline $8 / 31 / 2007$ & 529 & 165 & 73 & 191 & 100 & & & & & & \\
\hline $\begin{array}{l}\text { Daily average in } \\
\text { the month }\end{array}$ & 697 & 152 & 133 & 315 & 118 & $\begin{array}{l}\text { Daily average in } \\
\text { the month }\end{array}$ & 463 & 196 & 80 & 133 & 54 \\
\hline $10 / 3 / 2008$ & 407 & 141 & 61 & 127 & 78 & $7 / 3 / 2009$ & 709 & 196 & 105 & 264 & 144 \\
\hline 10/10/2008 & 378 & 117 & 58 & 115 & 88 & $7 / 10 / 2009$ & 639 & 170 & 93 & 233 & 143 \\
\hline 10/17/2008 & 132 & 44 & 28 & 33 & 27 & $7 / 17 / 2009$ & 345 & 113 & 64 & 111 & 57 \\
\hline 10/24/2008 & 261 & 84 & 49 & 81 & 47 & $7 / 24 / 2009$ & 778 & 228 & 111 & 271 & 168 \\
\hline $10 / 31 / 2008$ & 212 & 77 & 50 & 59 & 26 & $7 / 31 / 2009$ & 581 & 150 & 78 & 217 & 136 \\
\hline $\begin{array}{l}\text { Daily average in } \\
\text { the month }\end{array}$ & 678 & 267 & 128 & 184 & 88 & $\begin{array}{l}\text { Daily average in } \\
\text { the month }\end{array}$ & 1023 & 364 & 204 & 313 & 142 \\
\hline
\end{tabular}

Source: our elaborations on "Rilevazione annuale dei matrimoni da fonti di stato civile, 2007-2009" 
Our results are worth comparing with those obtained by the 2010 Euro-barometer survey on the attitudes of Europeans towards scientific progress. In particular, according to that survey, $58 \%$ of Italian respondents claimed to believe to the existence of lucky/unlucky numbers. Only the Czech Republic and Latvia, at, respectively, 60 and $59 \%$, were higher. ${ }^{11}$

As further evidence of the surprising diffusion of superstitions in Northern-Central Italy with respect to Southern Italy, we used Google Trend to investigate how often Italians consult online horoscopes. Torgler (2007) suggested that the habit of consulting horoscopes may be indicative of a tendency to believe in a sort of institutionalized superstition that, however, has no scientific basis. Google Trend allows us to compare the popularity of search terms on Google. In particular, it offers an index of popularity, which is calculated by dividing the number of searches that include the query term (defined by the User) by the total number of online search queries submitted during a period defined by the User. This result is then normalized so that its maximum value over the period is set equal to 100, and the rest of the series is scaled appropriately, obtaining the so-called popularity index. Normalization using the total number of searches allows us to neutralize geographical differences in terms of web access across Italian regions. Unfortunately, this is the only way in which Google Trend data can be exploited by users: for instance, Google Trend does not furnish the actual number of searches and, thus, it does not allow us to compare interest between different topics.

To at least partly avoid the influence of Internet availability on our results, we limited the period of observation from January 2010 to January 2015. The results are reported in Fig. 2. Again, it is surprising to see that one Northern region (Lombardy) and one Central region (Latium) are the most assiduous in consulting horoscopes. Furthermore, when cities are considered, the first five positions in the popularity rank for horoscopes are as follows: Milan, with a popularity index (pop. index from now) equal to 100 (Northern Italy, capital of Lombardy); Rome (pop. index: 99); Bologna, with a pop. index equal to 80 (Northern Italy, capital of Emilia Romagna); Naples, with a pop. index equal to 74 (Southern Italy, capital of Campania); Turin, with a pop. index equal to 73 (Northern Italy, capital of Piedmont). Obviously, it is impossible to establish whether those who consult the horoscope make different daily decisions as a result. In the case of marriages, it is difficult to reconcile other possible explanations for avoiding ceremonies on the 17th (which in principle is as good as any other day in the month). However, in the case of horoscopes, even if suggestive, this is a further descriptive element to add to the overall picture showing that despite the North-South economic gradient, beliefs in mysterious forces (luck, cosmic influence, etc.) are still strong across the country as noted by (Federici 1964).

In regard to religious beliefs, as reported above in the second section of this work, the demographic literature has shown that the Catholic Church's prohibition on celebrating marriages during Lent and Advent operated as a significant deterrent for those periods. Referring to Lent dispositions, Federici (1964) noted that, in 1958, the daily average of weddings during Easter week stood at 77 in Italy (333, if we consider the whole of Lent), against a daily mean of 1023 marriages for the year. Furthermore, an explosion in the number of marriages was observed during the week immediately following Easter week (daily average of the week 2741 marriages). Thus, we seem to see here weddings that were postponed so as not to violate the Lenten ban. In regard to 


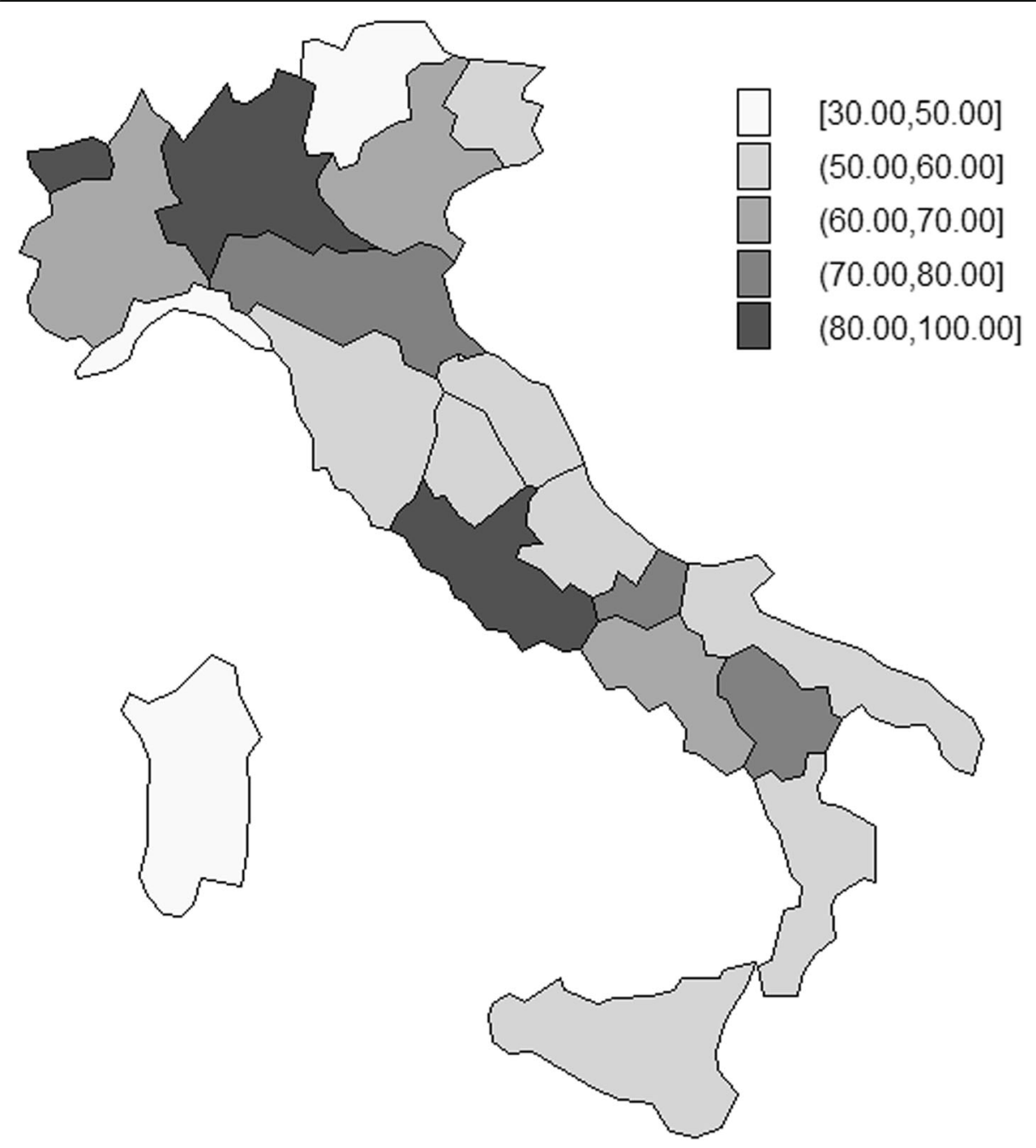

Fig. 2 Google Trend Population Index of the query "horoscope". Italian regions, 2010-2015

territorial differences, Federici also reported that the Lenten ban was strongly respected across the country and that North Eastern Italy had the strongest adherence to this religious norm. Recent work carried out by Ruiu and Breschi (2015) shows that Lenten dispositions are still responsible for fluctuations in the number of marriages celebrated in April in Italy. In particular, they use data, from the creation of the Italian state in 1861 to the present day, and exploit the variability in the number of Lent days falling in April in each year. They show that there is a strong and significant correlation, even in recent times, between the oscillations on April Lent days and the de-trended number of marriages celebrated in this month. Unfortunately, their analysis was based on data aggregated at the regional level and, therefore, they were not able to analyse the tendency with respect to the Lenten rule in function of the socio-demographic characteristics of the spouses.

Before comparing Federici's findings with those of the modern day, it may be worth examining the territorial diffusion of religious marriages, as a more general indication of secularization in Italy. In particular, in Fig. 3, we report the percentage of marriages celebrated with the religious rite in each Italian province in the period 2007-2009. We do not have this data for the period analysed by Federici. However, in 1958, $98.2 \%$ of 


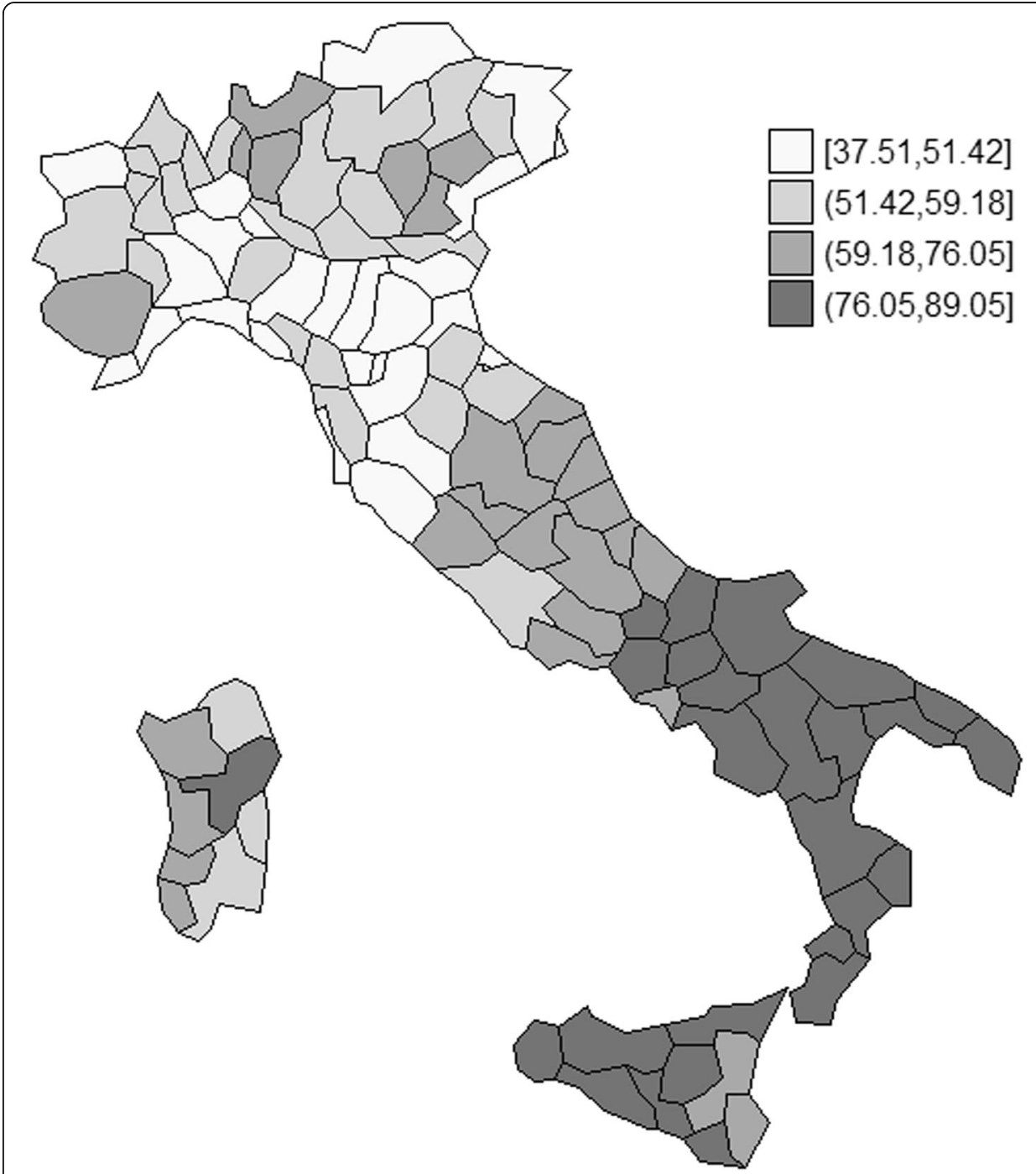

Fig. 3 Percentage of religious marriages out of total celebrations, 2007-2009

marriages in Italy were celebrated with the religious rite. It can be safely assumed, then that almost all marriages were celebrated in church. ${ }^{12}$

In Fig. 3, the darker colour indicates a higher percentage of religious marriages. It is immediately evident that, in the South (with the exception of Sardinia), the vast majority of celebrations take place in a church (in Sicily, Apulia and Calabria, more than $80 \%$ of marriages were celebrated with the religious rite). ${ }^{13}$

Finally, considering Lent, Table 3 reports the absolute number of religious marriages celebrated in Italy during Holy Week in the 3 years, 2007-2009, during the week before

Table 3 Absolute numbers of religious marriages celebrated during Holy Week, 2007-2009

\begin{tabular}{llllll}
\hline & Italy & North & Centre & South & Island \\
\hline Week before Holy Week 2007-2009 & 1479 & 458 & 269 & 627 & 125 \\
Holy Week 2007-2009 & 187 & 79 & 30 & 66 & 12 \\
Week after Holy Week 2007-2009 & 8121 & 3356 & 1294 & 2390 & 1081 \\
\hline
\end{tabular}

Source: our elaborations on "Rilevazione annuale dei matrimoni da fonti di stato civile, 2007-2009" 
Holy Week and the week after Easter. Because of the infrequency of the event, we were forced to put together the North West and North East, and to consider the 3 years together. We also want to stress that, since the Second Vatican Council, the Catholic Church has relaxed the constraints on celebrating Lenten marriages. In particular, the ban on the solemnization of marriages has been substituted by a milder recommendation for sobriety in any celebrations in what is, after all, a period of penance.

Here, too, we can conclude that very little has changed from the situation described by Federici. Despite the Church relaxing restraints, somewhat, the depressing effect of Holy Week means a $90 \%$ drop in the number of marriages in all macro-areas with respect to the previous week. It is, also, worth noting that the recovery in the number of marriages in the week immediately following Easter is still evident. Thus people are still likely to postpone marriages, rather than let them be celebrated in Easter week.

\section{An individual level analysis of the choice of marrying in church or during Lent}

In the previous section, we looked at the effects of both superstitions and religious beliefs on the timing of marriages in Italy. In this section, our aim is, first of all, to give a descriptive picture, in terms of socio-economic characteristics, to those whom, in 2007-2009, opted for a religious marriage. Then, we will focus on the choice of getting married in Lent. One might surmise that those aspects that favour the choice of the religious rite are negatively correlated with the choice of violating Lent: i.e. those who are more likely to opt for the religious rite are, at the same time, also less likely to violate the Lenten ban. If this is so, then, we have, in our opinion, an insight that the choice of the religious rite reflects an adherence to religious beliefs and not a choice about respecting the tradition of marrying in the church.

In Table 4, we investigate the individual characteristics that are associated with the choice of marrying with the religious rite. In particular, in column (a), we report the results of a logistic regression, where the dependent variable is a dummy that is equal to one when a marriage has been celebrated with the religious rite (obviously, it is equal to 0 in the case of civil marriage): the regressors are, meanwhile, a set of socio-demographic characteristics of the spouses (occupational status, educational level, age, nationality and previous civil status), in addition to the year and province fixed effects. In column (b), we reported the results of a linear probability model (LPM) estimated with the same left- and right-hand side variables. We are aware that given the dichotomous nature of our dependent variable this is not the most appropriate model. However, we also furnish the results of this estimation to ensure that our results do not depend on the assumption made on the link function in the logistic model. The names of the variables included in the r.h.s. of the regression are mostly self-explanatory, and greater detail will be given in the text when needed.

Unsurprisingly, the age of the spouses is negatively related to the probability of marrying with the religious rite. However, this is probably not because young people are more religious than older people. This effect is probably due to the fact that the younger the spouses, then the more likely they are to want to make their marriage an event that they will remember for the rest of their lives. In the vast majority of cases, getting married with the civil rite in Italy implies marrying in an anonymous office in the town hall: a religious ceremony means marrying in a church, possibly a cathedral, often, in Italy, a building of striking beauty. Therefore, younger couples are more likely to opt for the religious rite independently of religious sentiments (see Vignoli and Salvini 
Table 4 Socio-demographic characteristics associated with the choice of marrying with the religious rite: results from a multivariate logistic regression. Italy, 2007-2009

\begin{tabular}{|c|c|c|c|c|}
\hline & \multicolumn{2}{|l|}{ (a) Logit } & \multicolumn{2}{|c|}{ (b) Linear Probability Model } \\
\hline & Odds ratio & S.E. & Coeff. & S.E. \\
\hline Age of the groom & 0.955 & $(0.004)^{* * *}$ & -0.007 & $(0.001)^{* * *}$ \\
\hline Age of the bride & 0.989 & $(0.001)^{* * *}$ & -0.002 & $(0.001)^{* * *}$ \\
\hline \multicolumn{5}{|c|}{ Occupation of the groom (ref. white collar) } \\
\hline Entrepreneur & 1.113 & $(0.040)^{* * *}$ & 0.013 & $(0.004)^{* * *}$ \\
\hline Self-employed & 1.091 & $(0.032)^{* * *}$ & 0.010 & $(0.004)^{* * *}$ \\
\hline Other autonomous work & 0.912 & $(0.053)$ & -0.009 & $(0.008)$ \\
\hline Manager & 0.884 & $(0.040)^{* * *}$ & -0.025 & $(0.006)^{* * *}$ \\
\hline Blue collar & 0.984 & $(0.029)$ & -0.002 & $(0.004)$ \\
\hline Other dep. worker & 0.889 & $(0.039)^{* * *}$ & -0.021 & $(0.007)^{* * *}$ \\
\hline Unemployed & 0.491 & $(0.031)^{* * *}$ & -0.105 & $(0.011)^{* * *}$ \\
\hline Looking for a job & 0.433 & $(0.037)^{* * *}$ & -0.122 & $(0.016)^{* * *}$ \\
\hline Retired & 1.279 & $(0.093)^{* * *}$ & 0.097 & $(0.010)^{* * *}$ \\
\hline Student & 0.525 & $(0.039)^{* * *}$ & -0.105 & $(0.012)^{* * *}$ \\
\hline Unable to work & 0.378 & $(0.063)^{* * *}$ & -0.119 & $(0.018)^{* * *}$ \\
\hline Other & 0.638 & $(0.066)^{* * *}$ & -0.044 & $(0.013)^{* * *}$ \\
\hline \multicolumn{5}{|c|}{ Occupation of the bride (ref. white collar) } \\
\hline Entrepreneur & 0.855 & $0.023)^{* * *}$ & -0.026 & $(0.005)^{* * *}$ \\
\hline Self-employed & 0.798 & $0.022)^{* * *}$ & -0.036 & $(0.005)^{* * *}$ \\
\hline Other autonomous work & 0.829 & $0.039)^{* * *}$ & -0.025 & $(0.007)^{* * *}$ \\
\hline Manager & 0.889 & $0.029)^{* * *}$ & -0.022 & $(0.005)^{* * *}$ \\
\hline Blue collar & 0.822 & $0.027)^{* * *}$ & -0.029 & $(0.005)^{* * *}$ \\
\hline Other dep. worker & 0.867 & $0.043)^{* * *}$ & -0.017 & $(0.006)^{* *}$ \\
\hline Unemployed & 0.498 & $0.041)^{* * *}$ & -0.099 & $(0.011)^{* * *}$ \\
\hline Looking for a job & 0.594 & $0.047)^{* * *}$ & -0.070 & $(0.010)^{* * *}$ \\
\hline Retired & 0.725 & $0.095)^{* *}$ & -0.071 & $(0.013)^{* * *}$ \\
\hline Student & 0.471 & $0.023)^{* * *}$ & -0.103 & $(0.007)^{* * * *}$ \\
\hline Unable to work & 0.760 & $0.036)^{* * *}$ & -0.045 & $(0.008)^{* * *}$ \\
\hline Other & 0.271 & $0.059)^{* * *}$ & -0.190 & $(0.029)^{* * *}$ \\
\hline \multicolumn{5}{|c|}{ Education of the groom (ref. primary) } \\
\hline University degree & 1.734 & $(0.106)^{* * *}$ & 0.061 & $(0.009)^{* * *}$ \\
\hline Some university & 1.449 & $(0.077)^{* * *}$ & 0.034 & $(0.007)^{* * *}$ \\
\hline High school & 1.551 & $(0.096)^{* * *}$ & 0.044 & $(0.009)^{* * *}$ \\
\hline Middle school & 1.375 & $(0.081)^{* * *}$ & 0.026 & $(0.009)^{* * *}$ \\
\hline \multicolumn{5}{|c|}{ Education of the bride (ref. primary) } \\
\hline University degree & 1.511 & $(0.094)^{* * *}$ & 0.070 & $(0.008)^{* * *}$ \\
\hline Some university & 1.382 & $(0.071)^{* * *}$ & 0.055 & $(0.007)^{* * *}$ \\
\hline High school & 1.390 & $(0.077)^{* * *}$ & 0.053 & $(0.008)^{* * *}$ \\
\hline Middle school & 1.103 & $(0.059)^{*}$ & 0.014 & $(0.008)$ \\
\hline \multicolumn{5}{|c|}{ Prev. civ. status of the groom (ref. single) } \\
\hline Widower & 0.949 & $(0.101)^{* *}$ & -0.041 & $(0.015)^{* * *}$ \\
\hline Divorced & 0.058 & $(0.006)^{* * *}$ & -0.328 & $(0.015)^{* * *}$ \\
\hline
\end{tabular}


Table 4 Socio-demographic characteristics associated with the choice of marrying with the religious rite: results from a multivariate logistic regression. Italy, 2007-2009 (Continued)

\begin{tabular}{|c|c|c|c|c|}
\hline \multicolumn{5}{|l|}{ Prev. civ. status of the bride (ref. single) } \\
\hline Widowed & 0.543 & $(0.048)^{* * *}$ & -0.101 & $(0.013)^{* * *}$ \\
\hline Divorced & 0.069 & $(0.005)^{* * *}$ & -0.282 & $(0.008)^{* * *}$ \\
\hline \multicolumn{5}{|l|}{ Nationality (ref. both Italian) } \\
\hline Groom is Italian, bride is not Italian & 0.104 & $(0.006)^{* * *}$ & -0.363 & $(0.01)^{* * *}$ \\
\hline Groom is not Italian, bride is Italian & 0.077 & $(0.005)^{* * *}$ & -0.472 & $(0.01)^{* * *}$ \\
\hline Both not Italian & 0.050 & $(0.019)^{* * *}$ & -0.502 & $(0.036)^{* * *}$ \\
\hline \multicolumn{5}{|l|}{ Year (ref. 2007) } \\
\hline 2008 & 0.924 & $(0.012)^{* * *}$ & -0.0112 & $(0.002)^{* * *}$ \\
\hline 2009 & 0.886 & $(0.011)^{* * *}$ & -0.0188 & $(0.0021)^{* * * * *}$ \\
\hline Number & 727,572 & & 727,572 & \\
\hline McFadden's Pseudo $R^{2}$ & 0.350 & & & \\
\hline Adjusted $R^{2}$ & & & 0.384 & \\
\hline
\end{tabular}

2014, for a discussion of this issue). Vignoli and Salvini argue, indeed, that young spouses tend to get married with the religious rite for two reasons: first, the aesthetics of this kind of celebration; and second, the social pressure of parents and relatives. A further point is worth making here: since at the second marriage the bride and bridegroom are, in general, older than those who are marrying for the first time and given that the Catholic Church has always been intransigent about divorce, it is unlikely that those celebrating a second marriage will or, indeed, can choose a religious rite (this is confirmed by the results of our analysis). ${ }^{14}$ Therefore, the fact that younger people are more willing to opt for the religious rite may just demonstrate that younger people are more likely to make an occasion of their first marriage, while older couples are, in many cases, forced by Catholic norms to opt for the civil rite. However, since we are controlling for civil status, we believe that this criticism does not apply here.

Education (both for the groom and wife) is positively related to the likelihood of marrying with the religious rite. This result may seem counterintuitive. In fact, with respect to education, one may argue that more educated people tend to apply more scientific thinking. Therefore, they also tend to reject beliefs that posit the existence of supernatural forces. However, McCleary and Barro (2006), using survey data for 68 countries, find that, though religiosity tends to decline with economic development, not all dimensions of development work in the same way, with education exerting a positive effect on religiosity and urbanization exerting a negative one. They explain this finding, arguing that " $[R]$ eligious beliefs, like many theoretical hypotheses, require abstract thinking or 'faith'. If highly educated people are more capable of the speculative reasoning that is needed for intellectual inquiry, they may also be more able or willing to make the abstractions needed to support religious beliefs. From this perspective, more educated people might be more religious" (2006, p. 151). Our results, which were obtained with a completely different data source, seem to confirm McCleary and Barro's argument. It must be said that the usual empirical findings according to which the 
relation between the individual's educational level and religious attendance is positive (see also Iannaccone 1998) has recently been questioned. Hungerman (2011) used changing time at school (the years of compulsory attendance demanded by the state) as an instrument variable to identify the relationship between completed schooling and later religiosity. He found a negative relationship between the degree of religiosity and educational level among non-Catholic Christians in Canada.

Mocan and Pogoroleva (2014) followed the same approach and replicated this econometric analysis for eleven European countries, taking into account superstitious beliefs as well.

They confirmed that education reduces attendance and religious practices, as well as the propensity to believe in superstitions.

Even if we admit that the relationship between education and religiosity is complex and more empirical efforts have to be implemented to definitively establish its direction, in our opinion, the empirical strategy proposed by Hungerman has some drawbacks.

For instance, it may be argued that compulsory schooling reform is an effective way to increase the years of education, but only for those who would, otherwise, have left school earlier.

We suspect that these kinds of reforms do not influence those individuals who would have achieved a higher level of education, in any case.

If one is willing to accept the idea that educational attainment is related to cognitive ability, then it may be argued that the reform increases education levels only for less able individuals: those that, according to McCleary and Barro, have less capacity to make the speculative reasoning necessary to sustain religious beliefs. Therefore, even if an increase in education for "low ability individuals" may reduce their level of religiosity, this does not mean that this effect is linearly translated for all education levels. Among occupational status, entrepreneurs and the self-employed are those most likely to opt for the religious rite. This category of workers is the one that, in principle, might benefit more from a religious group's social network. Indeed, having a large social network may be of crucial importance for entrepreneurs in terms of information exchange, workforce recruitment and financial and social support (see Stuart and Sorenson 2005 for a discussion). However, this effect seems to disappear for female entrepreneurs. A possible interpretation of this gender difference can be traced in Renzulli et al. (2000). In particular, according to Renzulli and colleagues, female entrepreneurs tend to have networks that are mainly kin-based, while in comparison, male entrepreneurs tend to have more heterogeneous networks. Therefore, if male entrepreneurs are those that are more likely to establish a network outside the family circle, and possibly in the ambit of their religious group, it seems reasonable that they will be more likely to get married in church.

Spouses that are not Italian tend to opt for civil marriages. This result makes sense, of course. In fact, with this control variable, we are probably capturing the effect of not belonging to one of the religious faiths that has entered into an agreement with the Italian State for the civil recognition of religious marriages.

In Figure 5 in the Appendix, we report, with a thematic map, the results associated with provincial dummies. The results are very similar to those reported in Fig. 3.

Having given some evidence about the factors associated with the choice of marrying with the religious rite, we now focus on the choice of marrying in Lent.

In Table 5 we report a logistic regression (column a) and a LPM (column b), in which the dependent variable is a variable named lent that assumes a value equal to one when 
Table 5 Socio-demographic characteristics associated with the choice of marrying during the Lenten period: results from a multivariate logistic regression. Italy, 2007-2009

\begin{tabular}{|c|c|c|c|c|}
\hline & (a) Logit & (b) Linear Probability Model & & \\
\hline & Odds ratio & S.E. & Coeff. & S.E. \\
\hline Age of groom & 1.004 & $(0.005)$ & 0.001 & $(0.000)$ \\
\hline Age of wife & 1.005 & $(0.002)^{* *}$ & 0.001 & $(0.000)^{*}$ \\
\hline \multicolumn{5}{|c|}{ Occupation of the groom (ref. white collar) } \\
\hline Entrepreneur & 1.088 & $(0.038)^{* *}$ & 0.001 & $(0.000)^{* *}$ \\
\hline Self-employed & 1.101 & $(0.048)^{* *}$ & 0.002 & $(0.000)^{* * *}$ \\
\hline Other autonomous work & 1.127 & $(0.115)$ & 0.0018 & $(0.001)$ \\
\hline Manager & 1.054 & $(0.075)$ & 0.001 & $(0.001)$ \\
\hline Blue collar & 0.963 & $(0.032)$ & -0.001 & $(0.000)$ \\
\hline Other dep. worker & 1.216 & $(0.125)^{*}$ & 0.0037 & $(0.002)^{*}$ \\
\hline Unemployed & 1.295 & $(0.099)^{* * *}$ & 0.005 & $(0.002)^{* *}$ \\
\hline Looking for a job & 1.195 & $(0.167)$ & 0.003 & $(0.003)$ \\
\hline Retired & 1.193 & $(0.160)$ & 0.007 & $(0.004)^{*}$ \\
\hline Student & 1.537 & $(0.237)^{* * *}$ & 0.009 & $(0.004)^{* *}$ \\
\hline Unable to work & 1.709 & $(0.762)$ & 0.0136 & $(0.014)$ \\
\hline Other & 0.892 & $(0.236)$ & -0.002 & $(0.005)$ \\
\hline \multicolumn{5}{|c|}{ Occupation of the bride (ref. white collar) } \\
\hline Entrepreneur & 1.252 & $(0.054)^{* * *}$ & 0.004 & $(0.000)^{* * *}$ \\
\hline Self-employed & 1.148 & $(0.083)^{*}$ & 0.002 & $(0.001)^{*}$ \\
\hline Other autonomous work & 0.826 & $(0.105)$ & -0.003 & $(0.002)$ \\
\hline Manager & 0.893 & $(0.087)$ & -.002 & $(0.001)$ \\
\hline Blue collar & 1.006 & $(0.040)$ & 0.001 & $(0.000)$ \\
\hline Other dep. work & 1.098 & $(0.113)$ & 0.001 & $(0.002)$ \\
\hline Unemployed & 1.317 & $(.078)^{* * *}$ & 0.005 & $(0.001)^{* * *}$ \\
\hline Looking for a job & 1.341 & $(0.076)^{* * *}$ & 0.005 & $(0.000)^{* * *}$ \\
\hline Retired & 1.291 & $(0.331)$ & 0.007 & $(0.007)$ \\
\hline Housewife & 1.329 & $(0.071)^{* * *}$ & 0.005 & $(0.001)^{* * *}$ \\
\hline Student & 1.237 & $(0.094)^{* * *}$ & 0.003 & $(0.001)^{* *}$ \\
\hline Unable to work & 0.833 & $(0.740)$ & -0.003 & $(0.013)$ \\
\hline Other & 1.890 & $(0.516)^{* *}$ & 0.012 & $(0.007)^{*}$ \\
\hline \multicolumn{5}{|c|}{ Education of the groom (ref. primary) } \\
\hline University degree & 0.923 & $(0.118)$ & -.001 & $(0.002)$ \\
\hline Some university & 0.942 & $(0.165)$ & -0.001 & $(0.003)$ \\
\hline High school & 0.982 & $(0.133)$ & -0.001 & $(0.003)$ \\
\hline Middle school & 1.001 & $(0.130)$ & 0.001 & $(0.002)$ \\
\hline \multicolumn{5}{|c|}{ Education of the bride (ref. primary) } \\
\hline University degree & 0.779 & $(0.078)^{* *}$ & -0.005 & $(0.002)^{*}$ \\
\hline Some university & 0.778 & $(0.099)^{* *}$ & -0.005 & $(.003)$ \\
\hline High school & 0.865 & $(0.088)$ & -0.003 & $(0.002)$ \\
\hline Middle school & 0.946 & $(0.100)$ & -0.001 & $(0.003)$ \\
\hline
\end{tabular}


Table 5 Socio-demographic characteristics associated with the choice of marrying during the Lenten period: results from a multivariate logistic regression. Italy, 2007-2009 (Continued)

\begin{tabular}{lllll}
\hline Prev. marital status of the groom (ref. single) & & & & \\
Widower & 1.580 & $(0.362)^{* *}$ & 0.013 & $(0.007)^{*}$ \\
Divorced & 1.662 & $(0.198)^{* * *}$ & 0.013 & $(0.004)^{* * *}$ \\
Prev. marital status of the bride (ref. single) & & & & \\
Widow & 1.679 & $(0.308)^{* * *}$ & 0.015 & $(0.008)^{*}$ \\
Divorced & 1.501 & $(0.177)^{* * *}$ & 0.012 & $(0.004)^{* * *}$ \\
Nationality (ref. both Italian) & & & & \\
Groom is Italian, bride is not Italian & 1.604 & $(0.113)^{* * *}$ & 0.011 & $(0.002)^{* * *}$ \\
Groom is not Italian, bride is Italian & 1.737 & $(0.181)^{* * *}$ & 0.012 & $(0.003)^{* * *}$ \\
Both not Italian & 1.642 & $(0.580)$ & 0.012 & $(0.010)$ \\
Year (ref. 2007) & & & -0.005 & $(0.000)^{* * *}$ \\
2008 & 0.704 & $(0.024)^{* * *}$ & 0.001 & $(0.518)$ \\
2009 & 1.022 & $(0.030)$ & & \\
Number & 464,593 & 464,593 & & \\
McFadden's Pseudo $R^{2}$ & 0.021 & & & \\
Adjusted $R^{2}$ & & 0.0037 & & \\
\hline
\end{tabular}

In both columns, the dependent variable is a dummy equal to 1 when spouses have chosen to get married during Lent $*^{* *}<0.01 ;{ }^{* *}<0.05 ;{ }^{*}<0.10$. Cluster (at provincial level) robust standard errors reported; controlling for province fixed effects

a marriage has been celebrated during Lent and zero otherwise. Meanwhile, the regressors are the set of individual characteristics of the groom and bride already used in the analysis presented in Table 4, in addition to a set of dummies for each province of celebration. The sample is limited to all of the marriages celebrated with the religious rite in the 3 years, 2007-2009. To make Table 5 as clear as possible, we report the results associated with provincial dummies via a thematic map in Fig. 4.

In particular, in Fig. 4, we present the thematic map reporting the results associated with each provincial dummy. In this case, a lighter colour indicates a strong respect for religious norms. The colours are assigned on the basis of the odds ratios that are associated with each provincial dummy. These may be, in fact, interpreted as an indicator of a higher (or lower) inclination to obey the religious norm with respect to the province of reference (Rome).

Before commenting on territorial differences, we will focus here on individual factors. The age of the wife has a small positive (but statistically significant) effect on the probability of getting married during Lent. This is, again, compatible with the explanation of marriage as "an event to remember". In fact, marrying during Lent means sobriety in terms of church decorations, musical accompaniment, and the like, thus, we would suggest, younger spouses are reluctant to marry in this period. ${ }^{15}$

Better educated people tend to avoid the period of religious penance, in comparison to less educated peers. Interestingly, the role of education is only statistically significant for the bride. A possible explanation for this is that education makes people more inclined to follow the rules that their communities impose. Glaeser and Sacerdote (2008) offer an alternative explanation of this result. They argue that education increases returns from networks and other forms of social capital. Therefore, better educated 


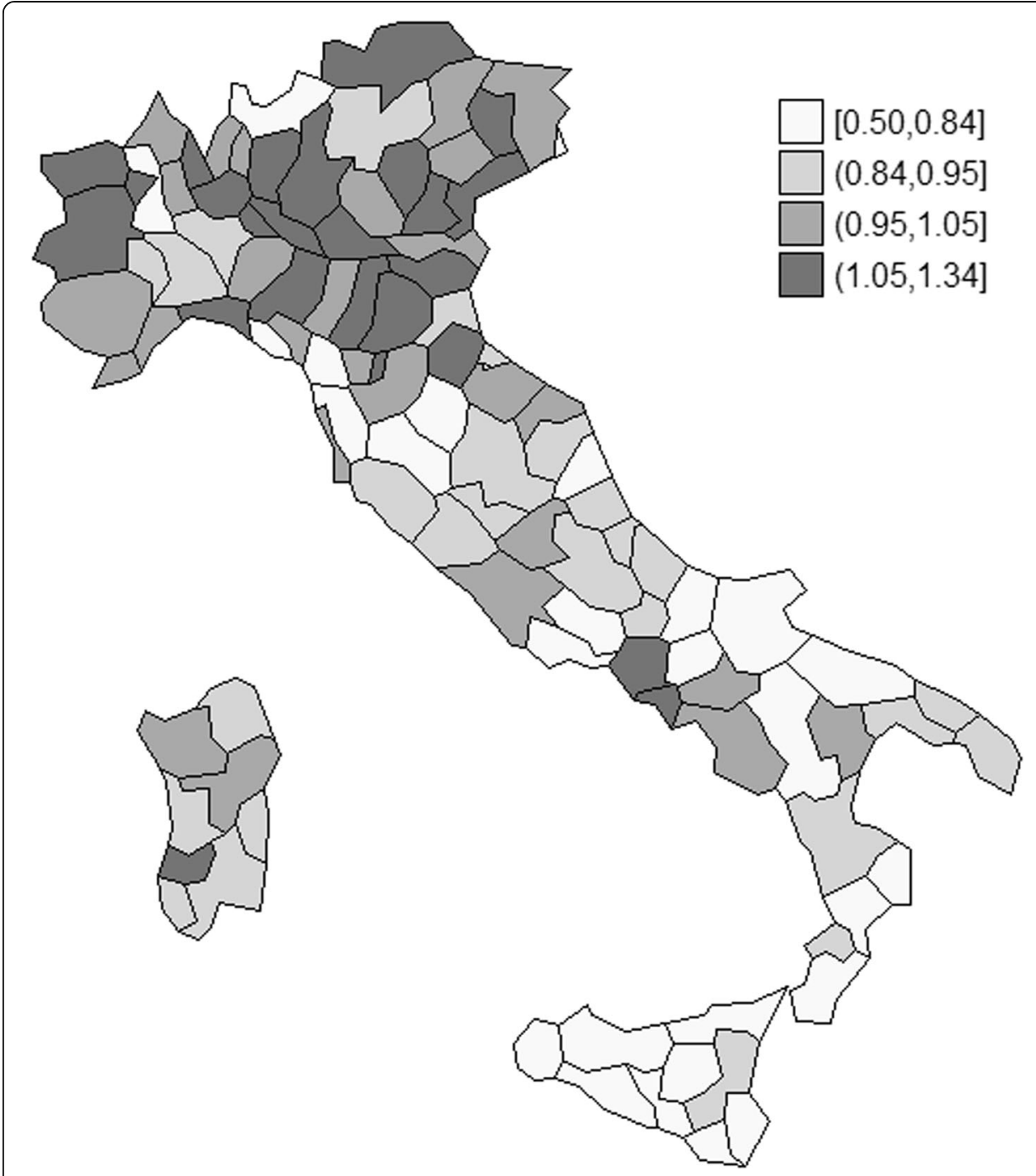

Fig. 4 Provincial differences in the tendency to get married during Lent, 2007-2009

people would participate in various group activities, including religious services, because this is a way to build social capital. The fact that only female education seems to be important is probably due to the fact that marriages are traditionally organized by the bride's family.

Additionally, occupational status seems to be highly significant in statistical terms for both the groom and bride. In general, those who are unemployed or looking for a job are more likely to get married in this period of the year. A possible explanation here is wedding costs. As reported above, the cost varies with the period chosen, therefore, opting for a period in which weddings are infrequent allows for a cheaper wedding. ${ }^{16}$ A different motivation might be relevant for entrepreneurs and the self-employed. In particular, it is reasonable to assume that, with Easter, the pace of work for a private firm is slower than during many other periods of the year (small Italian firms tend to have Easter holidays), and this may reduce the cost of marrying in that period. 
We are able, in our data source, to distinguish whether or not a wedding has been celebrated with the religious rite, but, unfortunately, we are unable to distinguish the religious faith to which the spouses belong. This effect may be, in part, the result of spouses coming from another country and other religious traditions. Indeed, when one of the spouses is not Italian, the probability of observing a marriage during Lent increases. A possible explanation for this is that when one of the spouses is not Italian, the weight of the cultural traditions of the other spouse is eased. This would be either because one of the spouses is not Catholic or because he or she comes from a Catholic country where the Lent prescription was not enforced. If this interpretation is corrected, it may seem surprising that there is not a statistical significant difference between couples in which the spouses are Italian or where neither are Italian. However, in Table 4, we show that when neither spouses are Italian, they are very unlikely to marry with the religious rite. Therefore, the results are probably influenced by the extreme rareness of the event.

In regard to territorial differences, the Centre and South are more inclined to get married in church and to avoid Lenten weddings. This result may seem to contrast with that reported by Ruiu and Breschi (2015). In particular, they claim that the North is more likely to respect religious precepts. However, it must be noted that the results of the two works are not directly comparable in empirical terms. In fact, Ruiu and Breschi's analysis is based on annual regional data on the number of celebrations in April. As such, we must consider a much wider interval of time (approximately 30 years), while estimating a mean effect for this time interval on the fluctuations in April marriages, in terms of Lenten days that fall in this month. Therefore, if we want to measure change, it makes more sense to compare the picture of the country taken by Federici (1964) with the one proposed in this work, rather than Ruiu and Breschi (2015), who aimed to describe the transition from the old model of wedding seasonality to the current one, a change that naturally took place over a long period.

Finally, considering the results associated with year dummies, we find that, in 2008, Italian spouses were more careful in avoiding the Lenten period with respect to 2007, while there is not a statistical significant difference between 2009 and 2007. Why? The great recession started in the USA in 2007, but the economic emergency began for Italy only in 2008. One possibility is that economic distress made people more careful in respecting religious norms, but after a period of adaptation they turned back to a previous level of religiosity. In our opinion, this issue could be better explored both with qualitative interviews and with more detailed data on church attendance.

\section{Conclusions}

In her concluding remarks, Nora Federici (1964) left, to future researchers, the task of testing whether economic developments and improvements in education levels would see Italians be less subject to superstitions and religious beliefs.

What has changed from the times of the Italian economic miracle to the present?

From an economic and demographic point of view, the immediate answer is surely "everything". However, if we focus on superstitions, we have shown that the 
whole country (with marginal differences among macro-areas) is very careful to avoid marriages on unlucky days: Tuesday and the 17th day of each month, with a further compounding effect produced when the 17th falls on a Friday (the day regarded by the Italian folklore as the most ominous). Using Google Trend data, we have also shown that another form of superstition, namely horoscopes, is more diffused in Northern Italy than in Southern Italy. However, while it is difficult to reconcile the avoidance of the 17th to anything other than superstition, we are unable to judge whether people are influenced in their daily actions by what they read in their horoscopes.

In regard to religion, we observed larger differences with respect to the picture offered by Federici. In particular, Northern Italy seems to be more secular than Southern Italy, even if religious dispositions still influence marriage seasonality as noted by Ruiu and Breschi (2015). Our work completes their analysis by explaining which factors are the most plausible drivers for secularization in the North. It must also be said that this difference may be, at least in part, attributed to the larger incidence of mixed nationality couples in the North, which perhaps eased the weight of a religious tradition that was once dominant across Italy (see ISTAT 2011).

How can we reconcile the persistence of superstitious beliefs with the observed secularization of religion?

Using McCleary and Barro's words: “...[O]ne conclusion is that religious beliefs and superstitious beliefs are very different. A possible reason is that religious beliefs are compatible with increased education and knowledge, whereas the superstitious beliefs are not" (2006, p. 169). Therefore, according to McCleary and Barro, education is positively associated with religiosity (this aspect is confirmed by our empirical results), but negatively associated with superstitions. McCleary and Barro also show that not all dimensions of economic development act in the same way as secularization. For instance, urbanization is found to be negatively correlated with religiosity. This may explain why the South, which is less economically developed, is also less secularized. On the other hand, this does not help explain the intriguing puzzle of the persistence of superstitions.

An analysis of the relationship between religious beliefs and superstitions carried out by Torgler (2007) offers food for thought here. Torgler finds that being an adherent to a religious faith is positively related to the probability of believing in superstitions: perhaps there is a predisposition among the religious to accept the existence of supernatural forces. However, at the same time, being actively religious exerts a negative effect on the probability that this is able to completely offset the first positive effect: Torgler's finding is compatible with the efforts made by the Catholic Church to eradicate the supernatural heritage of the pagan era.

Therefore, a possible explanation for the paradox may be formulated as follows: economic progress (with the exception of education) means the secularization of religious beliefs. This, in turn, may lead to a re-emersion of superstitious beliefs, if economic progress is not able to completely compensate for the effect of declining religiosity. This interpretation is coherent with another finding reported by McCleary and Barro (2006), according to which, in the former Soviet countries, where religious practices were limited by the Communist regime, there is both a low level of religiosity and a generalized tendency to believe in superstitions. This 
is, for instance, the case in a high income, high-level secularized country, such as Latvia, while it is not the case for a low income, low-level secularized country like Romania.

If this interpretation is correct, a clear policy suggestion for combating superstitions would be to improve education, which, at the same time, seems not to be a determinant of religious secularization.

Finally, we want to again stress Nora Federici's achievement in individuating a research topic that, despite the current disinterest in wedding seasonality, is, in our opinion, still rich in promise, not only for demographers but also for social scientists, more generally.

\section{Endnotes}

${ }^{1}$ We limited ourselves to the demographic periodicals that have a long tradition (they have been continuously published from at least 1975), namely Demography, Genus, Population Studies, International Migration Review, Population and Development Review, Studies in Family Planning and Population. For the period 1975-1984, the research engine offers 859 research articles; 974 for 1985-1994; 823 for 1995-2004; but only 456 for 2005-2014We also want to stress that in the ambit of historical demography, there is perhaps a less visible decline due to a lack of other data sources. The seasonality of weddings is still used to infer information on the level of development in a given society.

${ }^{2}$ However, this observation is not limited to Italy or wedding seasonality. For instance, (Rau 2007) argued that: "Nowadays, seasonal effects in demographic variables are rarely the centre of attention in population studies - although most basic indicators such as births, deaths, marriages...are subject to annual fluctuations. The last monograph on seasonality in mortality was published more than 25 years ago." (p. 2).

${ }^{3}$ Nora Federici (1910-2001) was the first woman to receive the IUSSP Laureate Award in 1992. For more details on her scientific activity see (Sonnino 2001).

${ }^{4}$ According to Italian folklore, on Tuesday and Friday, weddings must be avoided, while the number 17 (instead of 13 in the English-speaking world) is considered to be a day of ill fortune.

${ }^{5}$ These data are considered sensitive and are, therefore, protected by severe privacy norms. This means that their use for research purposes is only admitted after official authorization by the central direction of ISTAT. To further ensure privacy, researchers must also elaborate the data in ISTAT's laboratories, without ever taking possession of the data source.

${ }^{6}$ In particular, the macro-areas are composed of as follows: North West-Lombardy, Piedmont, Aosta Valley, Liguria; North East-Trentino Aldo Adige, Veneto, Friuli Venezia Giulia; Centre-Emilia Romagna, Tuscany, Umbria, Latium, Marche; South-Campania, Abruzzo, Molise, Apulia, Calabria, Basilicata; Islands-Sicily, Sardinia.

${ }^{7}$ Consider, for example, that the city of Bologna allows civil celebrations from Thursday to Sunday from 9.30 a.m. to 12.30 p.m.; Turin allows weddings on Monday, Thursday and Saturday (on Saturday, with a fee); while, in Naples, weddings can, in principle, be celebrated on all days of week, but with an extra fee on 
Saturdays and Sundays: i.e. the cost for the celebration is $€ 200$ on a working day, rising to $€ 500$ for Sunday.

${ }^{8}$ In Apulia, there is also a similar disposition of the curia.

${ }^{9}$ According to this norm, it is not possible to produce descriptive statistics that involve fewer than ten statistical units.

${ }^{10}$ Emilia Romagna has been considered as part of the North macro-area so as to not violate the ten units rule. Note that this region is usually considered as a Northern region in Italian official statistics. The exception is Federici's decomposition and not the one proposed in Table 3.

${ }^{11}$ Source: http://ec.europa.eu/public_opinion/archives/ebs/ebs_340_en.pdf

${ }^{12}$ This assumption is also, in part, supported by the fact that divorce only entered the Italian legal system in the year 1970. Therefore, prior to 1970, second civil marriages of separated couples were not allowed.

${ }^{13}$ This result is, in part, driven by the fact that in Northern Italy, both mixed nationality marriages and second marriages of divorced people are more diffused than in Southern Italy (see ISTAT 2011).

${ }^{14}$ Note that if a divorced person comes from a religious marriage, Catholic norms exclude the possibility of a second religious marriage, while this is not true in the case of a first civil marriage (i.e. a divorced person from a former civil marriage could in principle celebrate his/her second marriage with a Catholic rite).

${ }^{15}$ As an anonymous referee pointed out, one may test for the presence of nonlinearity in the relation between age and religiosity by including a set of dummies for different age classes. Even if the literature signals the possibility of this nonlinearity (see Argue et al. 1999), this econometric exercise would seem more useful for an analysis of church attendance or self-perceived degrees of religiosity. As this study focused on weddings, the sample includes a very small proportion of older spouses, who are concentrated in the categories "widowed", "widower" or "retired". In this case, it will be impossible to empirically distinguish the effect of being in the "older age" class from that of coming from a previous marriage. See Table 6 in the Appendix for some descriptive statistics reporting the age of spouses in terms of their previous marital status.

${ }^{16}$ The survey carried out by Federconsumatori reported that, in Italy, in 2009, a wedding with 100 guests costs on average $€ 27,000$.

\section{Appendix}

Table 6 Average age at the marriage by previous marital status. Italy 2007-2009

\begin{tabular}{|c|c|c|c|c|c|c|c|c|}
\hline \multirow[t]{2}{*}{ Year } & \multicolumn{4}{|l|}{ Groom } & \multicolumn{4}{|l|}{ Bride } \\
\hline & Single & Widower & Divorced & All status & Single & Widowed & Divorced & All status \\
\hline 2007 & 32.64 & 61.49 & 47.87 & 34.17 & 29.93 & 48.93 & 42.31 & 30.96 \\
\hline 2008 & 32.90 & 61.22 & 48.08 & 34.47 & 30.16 & 48.41 & 42.57 & 31.25 \\
\hline 2009 & 33.12 & 60.90 & 48.34 & 34.76 & 30.39 & 48.33 & 42.90 & 31.51 \\
\hline
\end{tabular}

Source: Istat, Rapporto annuale sui matrimoni in Italia, 2009 


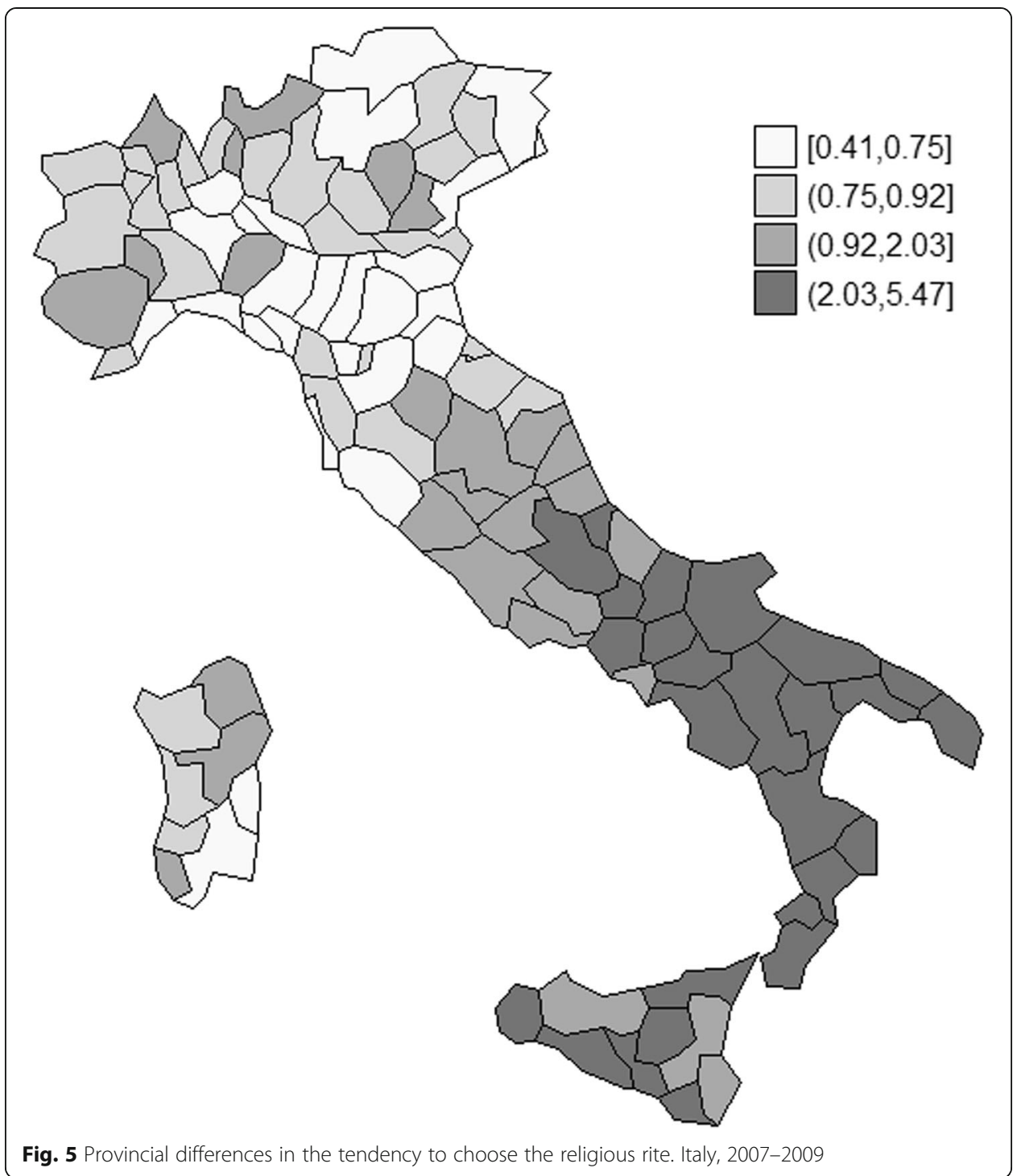

\section{Acknowledgements}

All the elaborations of the data coming from the "Rilevazione annuale dei matrimoni" were carried out at the Laboratory for the Analysis of Elementary Data (ADELE) at the ISTAT regional office of Cagliari and performed in compliance with all the regulations regarding the protection of statistical confidentiality and of personal data. The findings and views expressed are solely the responsibility of the authors and do not represent official statistics. We want to thank the personnel of the ISTAT office of Cagliari for their kindness and courtesy. A draft of this paper was presented at the Conference of the Italian Society of Historical Demography held in Udine, 8-10 October 2015. We thank all participants for their comments.

Finally, we thank two anonymous referees for their valuable comments and suggestions that have significantly improved the quality and the robustness of the paper.

\section{Authors' contributions}

All authors have contributed equally to each section of the work. All authors have read and approved the final version of the document.

\section{Competing Interests}

The authors declare that they have no competing interests

Received: 4 February 2016 Accepted: 15 July 2016

Published online: 01 December 2016 


\section{References}

Angius, V. (2006). Città e villaggi della Sardegna dell'Ottocento. Nuoro: Illisso Editori.

Argue, A., Johnson, D. R., \& White, L. K. (1999). Age and religiosity: evidence from a three-wave panel analysis. Journal for the Scientific Study of Religion, 38(3), 423-435.

Arsenovic, D., Djurdjev, B., Pajtic, B., Marinkovic, D., \& Ivanovic-Bibic, L. (2015). Seasonality of marriages in the Sajkaska Region (North Serbia), 1869 to 2011. Journal of Family History, 40(4), 485-497. doi:10.1177/0363199015602929.

Barrett, R. E. (1990). Seasonality in vital processes in a traditional Chinese population: births, deaths, and marriages in colonial Taiwan, 1906-1942. Modern China, 16(2), 190-225.

Barro, R. J., \& McCleary, R. M. (2003). Religion and economic growth across countries. American Sociological Review, 68(5), 760-781. doi:10.2307/1519761.

Bonarini, F. (2013). Mutamenti dei comportamenti religiosi in Italia. Department of Statistical Sciences. University of Padua. Working paper Nr. 4, February 2013. Downloadble at: http://paduaresearch.cab.unipd.it/7116/1/2013_4_ 20130226130527.pdf

Bonneuil, N., \& Fursa, E. (2013). Secularisation and the religious components of marriage seasonality in the Don Army Territory (Southern Russia), 1867-1916. Continuity and Change, 28(1), 51-88. doi:10.1017/ S0268416013000106.

Bourgeois-Pichat, J. (1946). Le mariage comme coutume saisonnière, contribution à une étude sociologique de la nuptialité en France. Population, 1(4), 623-642.

Chiassino, G., \& Di Comite, L. (1972). Le Fluttuazioni Stagionali dei matrimoni in Italia. Rassegna Economica del Banco DI Napoli, XXXVI (Nov-Dic), 1535-1553.

CISP. (1941). Fonti archivistiche per lo studio dei problemi della popolazione fino al 1848. Roma: Tipografia Consorzio Nazionale.

Coppa, A., Donato, L. D., Vecchi, F., \& Danubio, M. E. (2001). Seasonality of marriages and ecological contexts in rural communities of central-Southern Italy (Abruzzo), 1500-1871. Collegium Anthropologicum, 25(2), 403-412.

Corridore, F. (1906). La periodicità nei fenomeni collettivi. Giornale degli Economisti, 33(17), 475-495.

Di Nola, A. M. (1993). Lo specchio e l'olio. Le superstizioni degli Italiani. Bari: Editori Laterza.

Dribe, M., \& van De Putte, B. (2012). Marriage seasonality and the industrious revolution: southern Sweden, 1690-1895. Economic History Review, 65(3), 1123-1146.

Federici, N. (1955). Lezioni di demografia. (M. Gaspare, Ed.) (1st ed.). Roma: Edizioni Universitarie.

Federici, N. (1960). Lezioni di Demografia. (R. Lenzi, Ed.) (2nd ed.). Roma: Libreria Editrice De Santis.

Federici, N. (1964). Sulle diversità territoriali delle oscillazioni periodiche dei matrimoni in Italia. Rivista Italiana di Economia, Demografia e Statistica, XVIII(3-4), 25-39.

Federici, N. (1965). Lezioni di Demografia. (R. Lenzi, Ed.) (3rd ed.). Roma: Libreria Editrice De Santis.

Federici, N. (1981). Istituzioni di Demografia. Roma: Editrice Elia.

Ferigo, G. (1998a). II mês di mai si maridin.... In Tradizioni, società e cultura in Val Pontaiba (pp. 99-123). Pasian di Prato: Atti del convegno, Treppo Carnico, 2 agosto 1998, Coordinamento Circoli culturali della Carnia.

Ferigo, G. (1998b). I nuviz, la fantâsima, il mus. Note sull'interdizione matrimoniale di maggio. Secoli XVI-XIX. Ce fastu?, LXXIV(2), 199-251.

Fernandez, R., \& Fogli, A. (2009). Culture: an empirical investigation of beliefs, work, and fertility. American Economic Journal: Macroeconomics, 1(1), 146-177.

Forgione, M. (2015). II matrimonio lucano e il suo universo culturale : lo specchio di una società che cambia. Antrocom Journal of Anthropology, 11(1), 125-152.

Glaeser, E. L., \& Sacerdote, B. I. (2008). Education and religion. Journal of Human Capital, 2(2), 188-215.

Golini, A. (1966). Bibliografia delle opere demografiche in lingua italiana. Roma: Facoltà di Scienze Statistiche Demografiche ed Attuariali - Università di Roma.

Golini, A., \& Caselli, G. (1973). Bibliografia delle opere demografiche italiane (1966-1972). Roma: Facoltà di Scienze Statistiche Demografiche ed Attuariali - Università di Roma.

González-Martín, A. (2008). Ecological and cultural pressure on marriage seasonality in the principality of Andorra. Journal of Biosocial Science, 40(1), 1-18. doi:10.1017/S0021932007002234.

Guiso, L., Sapienza, P., \& Zingales, L. (2003). People's opium? Religion and economic attitudes. Journal of Monetary Economics, 50, 225-282. doi:10.1016/S0304-3932(02)00202-7.

Houdaille, J. (1978). Un indicateur de pratique religieuse : la célébration saisonnière des mariages avant, pendant et après la révolution française. Population, 33(2), 367-380.

Hungerman, D. M. (2011). The effect of education on religion: evidence from compulsory schooling laws, NBER working paper No. 16973.

Iannaccone, L. R. (1998). Introduction to the economics of religion. Journal Of Economic Literature, 36(3), $1465-1495$.

ISTAT. (2011). I matrimoni in Italia, anno 2009 e dati provvisori 2010. http://www.istat.it/it/files/2011/05/ testointegrale20110518.pdf?title=Matrimoni+in+Italia+-+18\%2Fmag\%2F2011+-+Testo+integrale.pdf.

Kaku, K., \& Matsumoto, Y. S. (1975). Influence of a folk superstition on fertility of Japanese in California and Hawaii, 1966. American Journal of Public Health, 65(2), 170-174.

Lesthaeghe, R., \& Lopez-Gay, A. (2013). Spatial continuities and discontinuities in two successive demographic transitions: Spain and Belgium, 1880-2010. Demographic Research, 28(January), 77-136. doi:10.4054/DemRes.2013.28.4.

Lesthaeghe, R. O. N., \& Surkyn, J. (1988). Cultural dynamics and economic theories of fertility change. Population and Development Review, 14(1), 1-45.

Livi-Bacci, M. (2000). Para la Revista/Boletín de la ADEH. Boletín de Demografía histórica, XVIII(II), 79-88.

Lucchetti, E., Manfredini, M., Boetsch, G., Bley, D., Aluja, P., Pena, J., et al. (1996). Change in marriage seasonality among some European rural population. Internation journal of Anthropology, 11(2-4), 73-81.

Lutinier, B. (1987). La saison des mariages. Economie et statistique, 204(November), 21-28.

McCleary, R. M., \& Barro, R. J. (2006). Religion and political economy in an international panel. Journal for the Scientific Study of Religion, 45(2), 149-175. 
Mocan, N., \& Pogoroleva, L. (2014). Compulsory Schooling Laws and Formation of Beliefs: Education, Religion and Superstition, IZA Discussion Paper No. 8698.

Monger, G. (1994). "To marry in May": an investigation of a superstition. Folklore, 105, 104-108.

Perrenoud, A. (1983). Calendrier du mariage et coutume populaire : le creux de mai en Suisse romande. Population, 38(6), 925-939.

Rau, R. (2007). Seasonality in Human Mortality. A demographic approach. Demographic Research Monographs Series, Heidelberg: Springer-Verlag. doi:10.1007/978-3-540-44902-7.

Renzulli, L. A., Aldrich, H., \& Moody, J. (2000). Family matters : gender, networks, and entrepreneurial outcomes. Social Forces, 79(2), 523-546.

Ruiu, G., \& Breschi, M. (2015). For the times they are a changin'. Demographic Research, 33(July), 179-210. doi:10.4054/ DemRes.2015.33.7.

Salvat, M., Vigo, M., Macbeth, H., \& Bertranpetit, J. (1997). Seasonality of marriages in Spanish and French parishes in the Cerdanya Valley, eastern Pyrenees. Journal of Biosocial Science, 29(01), 51-62.

Sanna, E., \& Danubio, M. E. (2008). Seasonality of marriages in Sardinian pastoral and agricultural communities in the nineteenth century. Journal of Biosocial Science, 40(04), 577-586. doi:10.1017/S0021932007002684.

Sonnino, E. (1997). La Demografia Storica Italiana 1940-1980 con integrazione 1981-1993. In Bollettino di Demografia Storica (pp. 26-27). Special Number).

Sonnino, E. (2001). Nora Federici (1910-2001). Popolazione e Storia, 2, 133-138.

Stuart, T. E., \& Sorenson, O. (2005). Social networks and entrepreneurship. In S. A. Alvarez, R. Agarwal, \& O. Sorensen (Eds.), Handbook of Entrepreneurship Research (pp. 233-252). New York: Springer.

Tabellini, G. (2010). Culture and institutions: economic development in the regions of Europe. Journal of European Economic Association, 8(4), 677-716.

Torgler, B. (2007). Determinants of superstition. Journal of Socio-Economics, 36(5), 713-733. doi:10.1016/.jsocec.2007.01.007.

Van Poppel, F. (1995). Seasonality of work, religion and popular customs: the seasonality of marriage in the nineteenthand twentieth century Netherlands. Continuity and Change, 10(2), 215-256.

Vignoli, D., \& Salvini, S. (2014). Religion and union formation in Italy: Catholic precepts, social pressure, and tradition Demographic Research, 31(November), 1079-1106. doi:10.4054/DemRes.2014.31.35.

\section{Submit your manuscript to a SpringerOpen ${ }^{\circ}$ journal and benefit from:}

- Convenient online submission

- Rigorous peer review

- Immediate publication on acceptance

- Open access: articles freely available online

- High visibility within the field

- Retaining the copyright to your article 